Available online on 15.06.2020 at http://jddtonline.info
Open Access to Pharmaceutical and Medical Research
(c) 2011-18, publisher and licensee JDDT, This is an Open Access article which permits
unrestricted non-commercial use, provided the original work is properly cited

Open $\odot$ Access

Research Article

\title{
Formulation and Evaluation of Piroxicam Fast Dissolving Tablets Using Direct Compression and Sublimation Method
}

\author{
Inder Kumar1*, Dipima Chaudhary², Bhumika Thakur ${ }^{3}$, Vinay Pandit ${ }^{2}$ \\ 1 School of Pharmacy, Abhilashi University Mandi HP, India \\ 2 Laureate Institute of Pharmacy, Kangra HP, India \\ ${ }^{3}$ Shiva Institute of B. Pharmacy, Bilaspur HP, India
}

\begin{abstract}
Objective: In the present research work, fast dissolving tablets of Piroxicam were formulated by two different techniques i.e. direct compression method and sublimation method using different superdisintegrants.

Methods: Twelve formulations were prepared (PXM1 to PXM12) in which first six formulation were prepared by direct compression technique and other six formulation were prepared by sublimation method by using camphor as a sublimating agent.

Result and Discussion: All the formulations were subjected for precompression, post compression parameters, and shows all the data within the specific limits. Formulation PXM4 containing $5 \%$ crospovidone showed $99.480 \pm 0.291 \%$ drug release in 20 min which was mo re than the drug release of rest of the formulations. The optimized formulation PXM4 was compared with the marketed formulation and it revealed that drug release of PXM4 was found to be $99.397 \pm 0.751 \%$ in 20 min, which was greater than the marketed formulation. Finally, re sults were statistically analysed by the application of one way ANOVA and t-test. The stability study of the optimized formulation PXM4 showed no significant changes in, drug content, disintegration time and in-vitro drug release.
\end{abstract}

Conclusion: Piroxicam can be successfully prepared using direct compression technique and it will enhance the drug dissolution, which will further increase absorption and bioavailability of the drug.

Keywords: Direct compression, fast dissolving tablets, sublimation, Piroxicam.

Article Info: Received 19 March 2020; $\quad$ Review Completed 18 May 2020; Accepted 24 May 2020; Available online 15 June 2020

\section{Cite this article as:}

Kumar I, Chaudhary D, Thakur B, Pandit V, Formulation and Evaluation of Piroxicam Fast Dissolving Tablets Using Direct Compression and Sublimation Method, Journal of Drug Delivery and Therapeutics. 2020; 10(3-s):17-25

http://dx.doi.org/10.22270/jddt.v10i3-s.4063

\section{*Address for Correspondence:}

Inder Kumar, School of Pharmacy, Abhilashi University Mandi HP, India

\section{INTRODUCTION}

A modern enhancement in Novel Drug Delivery System (NDDS) goals to improve safety and efficiency of formerly used drug molecule by formulating a suitable dosage form to achieve better patient acquiescence and ease of administration with enhanced bioavailability and enhanced efficacy, thus reducing the dose to reduce the side effects. ${ }^{1}$ Due to the unique properties, the Fast dissolving drug delivery system (FDDDS) has great reputation in the pharmaceutical industry. ${ }^{2}$ FDDDS in most cases is a tablet that dissolved in oral mucosa within seconds without need of water that makes them extremely attractive to pediatric and geriatric patients. ${ }^{3}, 4$ Nowadays, the demand of fast disintegrating tablets has immensely increased as it has major impact on patient compliance. ${ }^{5}$ According to European Pharmacopoeia, rapidly disintegrating tablets are those, which are placed in the oral cavity and disperse before swallowing in less than three minutes. ${ }^{4}$ The property of dispersibility is due to the addition of superdisintegrants to the dosage form, thus increasing the bioavailability by releasing the drug in mouth. 6,7 There are various conventional approaches to formulate the fast dissolving tablets. Addition of superdisintegrants is the basic approach that plays a vital role in the dissolution and disintegration for the development of the fast dissolving tablets. This is the most popular technique due to its cost effectiveness and easy implementation. ${ }^{8}, 9$ Drugs which are poorly water soluble (Class II) having slower rate of absorption, high permeability and low bioavailability due to less dissolution, so there is need to improve the dissolution rate of such drugs which may lead to the improvement of bioavailability and hence faster onset of action of drugs is achieved. ${ }^{10}$

Piroxicam, an oxicam is a non-selective cyclooxygenase - 2 inhibitor, used in the treatment of rheumatoid arthritis, 
osteoarthritis and other joint diseases but at high concentrations also inhibits polymorphonuclear leukocyte migration, decreases oxygen radical production, and inhibits lymphocyte function and it belongs to class-II of biopharmaceutical classification system which have low aqueous solubility. ${ }^{11}$ Therefore, the present research work is to formulate and evaluate of fast dissolving tablets Piroxicam in order to provide faster on set of action and better patient compliance.

\section{MATERIALS AND METHODS}

Piroxicam was obtained as gift sample from Lark laboratories, Bhiwadi, India. Sodium starch glycolate, croscarmellose sodium, microcrystalline stearate were obtained as gift sample from Maple biotech, Pune. Talc, camphor, mannitol and aspartame were procured from CHD fine chemicals, New Delhi and all other chemicals/solvents used were of analytical grade.

\section{Preformulation Studies}

All the Preformulation studies like melting point, solubility study, and partition coefficient were carried out effectively. $12-14$

\section{Determination of $\lambda_{\max }$ in methanol and phosphate buffer pH 6.8}

The absorption maxima of Piroxicam was determined in methanol and phosphate buffer $\mathrm{pH} 6.8$ by scanning the drug in the range of 400-200 $\mathrm{nm}$ using UV spectrophotometer.
Preparation of stock solution and calibration curve of Piroxicam

Standard stock solution $(100 \mu \mathrm{g} / \mathrm{ml})$ of Piroxicam was prepared in phosphate buffer $\mathrm{pH}$ 6.8. From this stock solution of phosphate buffer $\mathrm{pH} 6.8$ different aliquots of various concentration $(6,8,10,12,14,16,20 \mu \mathrm{g} / \mathrm{ml})$ were prepared. For phosphate buffer pH 6.8 absorbance was measured at $344 \mathrm{~nm}$, against similarly treated blank.

\section{Compatibility Studies of Piroxicam}

Dried samples were mixed with dried potassium bromide $(\mathrm{KBr})$ powder. The sample discs were prepared using $\mathrm{KBr}$ press at pressure of 10000 to 15000 psi. The sample disc was placed in the sample holder and scanned from 4000 to 400 $\mathrm{cm}^{-1}$ at a resolution of $4 \mathrm{~cm}^{-1} .15$

\section{Formulation of Tablets}

Fast dissolving tablets of Piroxicam were formulated by direct compression method and sublimation method using sublimating agent i.e. camphor. Different superdisintegrants were used (Sodium starch glycolate, crospovidone and croscarmellose sodium) with different concentration. In the present work, total 12 formulations were prepared i.e. PXM1 to PXM12 in which formulations PXM1 to PXM6 were prepared by direct compression method and PXM7 to PXM 12 were prepared by sublimation method. Table 1 and Table 2 respectively. ${ }^{16-18}$

Table 1: Composition of different batches of fast dissolving tablets of Piroxicam (Direct compression method)

\begin{tabular}{|c|c|c|c|c|c|c|c|}
\hline S. No. & Ingredients & $\begin{array}{c}\text { PXM1 } \\
(\mathrm{mg})\end{array}$ & $\begin{array}{c}\text { PXM2 } \\
(\mathrm{mg})\end{array}$ & $\begin{array}{c}\text { PXM3 } \\
(\mathrm{mg})\end{array}$ & $\begin{array}{c}\text { PXM4 } \\
(\mathrm{mg})\end{array}$ & PXM5 (mg) & PXM6 (mg) \\
\hline 1 & Piroxicam & 20 & 20 & 20 & 20 & 20 & 20 \\
\hline 2 & SSG & 6 & 10 & - & - & - & - \\
\hline 3 & CP & - & - & 6 & 10 & - & - \\
\hline 4 & CCS & - & - & - & - & 6 & 10 \\
\hline 5 & MCC & 102 & 98 & 102 & 98 & 102 & 98 \\
\hline 6 & Mannitol & 60 & 60 & 60 & 60 & 60 & 60 \\
\hline 7 & Aspartame & 8 & 8 & 8 & 8 & 8 & 8 \\
\hline 8 & Magnesium stearate & 2 & 2 & 2 & 2 & 2 & 2 \\
\hline 9 & Talc & 2 & 2 & 2 & 2 & 2 & 2 \\
\hline 10 & Menthol & q.s & q.s & q.s & q.s & q.s & q.s \\
\hline
\end{tabular}

Table 2: Composition of different batches of fast dissolving tablets of Piroxicam (Sublimation method)

\begin{tabular}{|c|c|c|c|c|c|c|c|}
\hline S. No. & Ingredients & $\begin{array}{c}\text { PXM7 } \\
\mathbf{( m g )}\end{array}$ & $\begin{array}{c}\text { PXM8 } \\
\mathbf{( m g )}\end{array}$ & $\begin{array}{c}\text { PXM9 } \\
\mathbf{( m g )}\end{array}$ & $\begin{array}{c}\text { PXM10 } \\
\mathbf{( m g )}\end{array}$ & $\begin{array}{c}\text { PXM11 } \\
\mathbf{( m g )}\end{array}$ & PXM12 (mg) \\
\hline $\mathbf{1}$ & Piroxicam & 20 & 20 & 20 & 20 & 20 & 20 \\
\hline $\mathbf{2}$ & SSG & - & - & 6 & 10 & - & - \\
\hline $\mathbf{3}$ & CP & 6 & 10 & - & - & - & - \\
\hline $\mathbf{4}$ & CCS & - & - & - & - & 6 & 10 \\
\hline $\mathbf{5}$ & MCC & 96 & 92 & 96 & 92 & 96 & 92 \\
\hline $\mathbf{6}$ & Mannitol & 60 & 60 & 60 & 60 & 60 & 60 \\
\hline $\mathbf{7}$ & Aspartame & 8 & 8 & 8 & 8 & 8 & 8 \\
\hline $\mathbf{8}$ & Magnesium stearate & 2 & 2 & 2 & 2 & 2 & 2 \\
\hline $\mathbf{9}$ & Talc & 2 & 2 & 2 & 2 & 2 & 2 \\
\hline $\mathbf{1 0}$ & Camphor & 6 & 6 & 6 & 6 & 6 & 6 \\
\hline
\end{tabular}

SSG-Sodium starch glycolate, CP-Crospovidone, CCS-Croscarmellose sodium, MCC-Microcrystalline cellulose. 


\section{Pre-Compression Studies}

Pre-compression studies like bulk density, tapped density, angle of repose, carr's index and hausner ration were carried out successfully. ${ }^{19-23}$

\section{Post Compression Studies}

The prepared tablets were evaluated for post compression studies, which are as follows:

\section{Weight variation:}

Randomly 20 tablets were selected from each formulation and weighed individually. Average weight was calculated and comparison was made between individual weight and average weight of tablets. ${ }^{24}$

\section{Thickness:}

The thickness was measured by placing tablet between two arms of the Vernier Caliper. ${ }^{25}$

\section{Hardness:}

The hardness of tablets was measured by Monsanto hardness tester. ${ }^{26}$

\section{Friability:}

Randomly twenty tablets were selected and weighed. These tablets were placed in the Roche friabilator test apparatus, which was then operated at 25 revolutions in a minute. After completion of 100 revolutions, the tablets were dusted and re-weighed. 27 The percent friability was calculated from the formula:

$$
\text { Friability }(\%)=\frac{\text { Initial weight }- \text { Final weight }}{\text { Initial weight }} \times 100
$$

\section{Drug content:}

Ten tablets from each formulation were crushed and the blend equivalent to one tablet was taken. The blend equivalent to one tablet was taken in a $100 \mathrm{ml}$ volumetric flask and volume was made up to mark with phosphate buffer ( $\mathrm{pH}$ 6.8). The flask was shaken for $24 \mathrm{hrs}$ using a water bath shaker. The solution was filtered and the filtrate was analyzed at $344 \mathrm{~nm}$ against similarly treated blank using UV-VIS spectrophotometer. ${ }^{28}$

\section{In-vitro disintegration time}

Six tablets were taken from all formulations and maintaining the water temperature at $37.0 \pm 0.5{ }^{\circ} \mathrm{C}$. Time taken for complete the disintegration of tablets was recorded by stopwatch. For accuracy, an average of six tablets was taken. ${ }^{29}$

\section{Wetting time:}

To determine the wetting time of tablets, five pieces of circular tissue paper was placed in the petri dish of diameter $10 \mathrm{~cm}$ containing $2 \mathrm{ml}$ of amaranth dye and $10 \mathrm{ml}$ of simulated saliva. The amaranth dye was used to identify complete wetting of the tablet surface. Now, the tablet was placed on the surface of the tissue paper in the petri dish containing dye at room temperature. The time-required dye to reach the upper surface of the tablets and the complete wetting of tablet was noted as the wetting time. ${ }^{29}$

\section{Water absorption ratio:}

For the determination of water absorption ratio, firstly weighed the tablets from each formulation before placing them into the petri plate containing $2 \mathrm{ml}$ of amaranth dye and $10 \mathrm{ml}$ of simulated saliva. Tablets were carefully removed from petri dish and weigh the wetted tablet. ${ }^{29}$ The water absorption ratio was calculated using the formula:

$$
\mathrm{R}=\frac{\mathrm{Wa}-\mathrm{Wb}}{\mathrm{Wa}} \times 100
$$

Where, $\mathrm{R}$ is water absorption ratio, $\mathrm{Wb}$ is weight of tablet before water absorption, and Wa is weight of tablet after water absorption.

\section{In-vitro dissolution studies:}

In-vitro dissolution study was carried out using USP dissolution test apparatus II at $50 \mathrm{rpm}$ in $900 \mathrm{ml}$ of phosphate buffer (pH 6.8) as a dissolution media and the temperature was maintained at $37 \pm 0.5 \stackrel{\circ}{\circ}$. The samples were withdrawn at fixed time intervals of $0,5,10,15,20$ min. Aliquots $(10 \mathrm{ml})$ were withdrawn, filtered and analyzed spectrophotometrically using UV spectrophotometer at 344 $\mathrm{nm}$. An equal amount of fresh dissolution medium, prewarmed at $37 \pm 0.5{ }^{\circ} \mathrm{C}$, was added after each sampling to maintain the sink condition throughout the study. ${ }^{30}$ The premising formulation was compared with the two different brands of marketed formulation by comparing in-vitro drug release.

\section{Statistical analysis}

The optimized formulation was analyzed using graph pad prism 7.0 version to generate statistical data. ANOVA was used to identify the significant effect. One way ANOVA, Brown-Forsythe test and Bartlett's test was used to analyze the data and the $\mathrm{P}$ value was calculated at $\mathrm{P}<0.05$ to identify the significant effect. 31

\section{Stability study of optimized batch}

To determine the drug and formulation stability, stability studies was performed according to ICH guideline under accelerated storage conditions. Tablets from the optimized batch were stored in stability chamber at temperature 45.0 ${ }^{\circ} \mathrm{C} \pm 2.0{ }^{\circ} \mathrm{C}$ and $75 \% \pm 5 \% \mathrm{RH}$ conditions for the period of 90 days. After 90 days, the tablets were evaluated for the physical appearance, drug content, and disintegration time and in-vitro drug release. ${ }^{17}$

\section{RESULTS AND DISCUSSION}

\section{Pre-formulation parameters}

Piroxicam was observed for organoleptic properties like physical appearance, odor, and melting point. The drug was identified with the help of UV and FTIR and exhibited absorption maxima at $344 \mathrm{~nm}$ when phosphate buffer $6.8 \mathrm{pH}$ was used as a solvent as mentioned in the literature. Differential scanning calorimeter shows endothermic fusion peak at $202.3^{\circ} \mathrm{C}$, which was corresponding to the melting point of Piroxicam. 


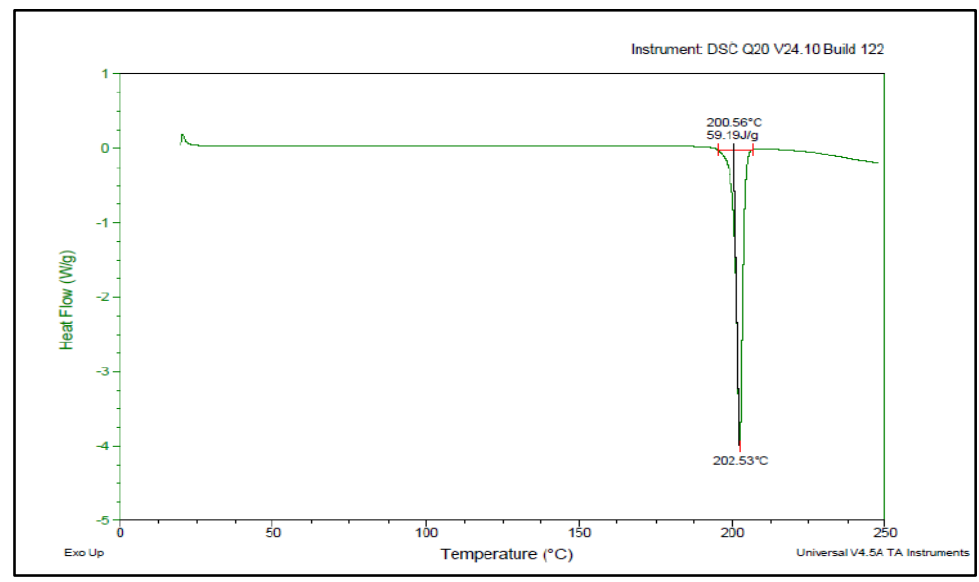

Figure 1: DSC Chromatogram of Piroxicam

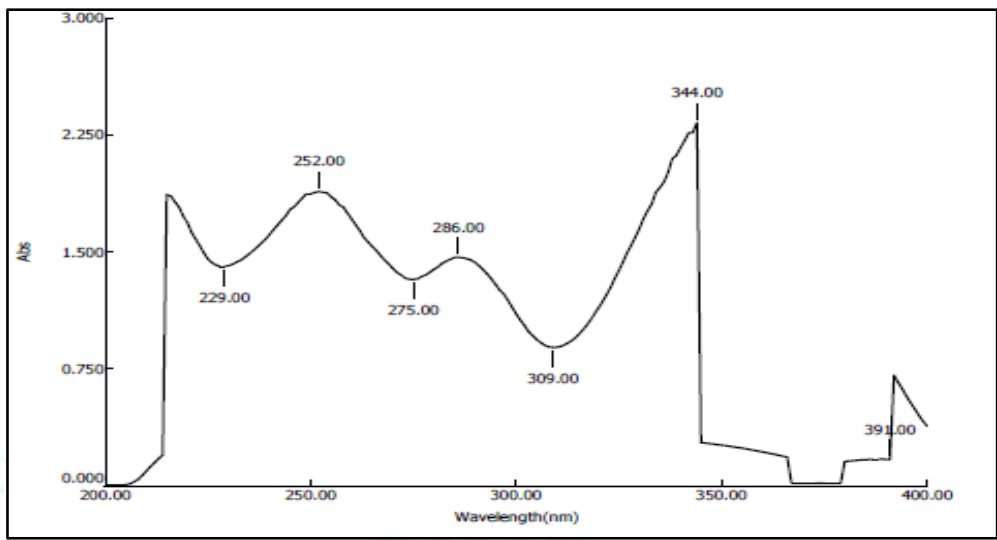

Figure 2: UV scan spectrum of Piroxicam in phosphate buffer pH 6.8

Table 3: Calibration curve data of Piroxicam in phosphate buffer pH 6.8

\begin{tabular}{|c|c|}
\hline $\begin{array}{c}\text { Concentration } \\
(\boldsymbol{\mu g} / \mathbf{m l})\end{array}$ & $\begin{array}{c}\text { Absorbance } \mathbf{\text { SD }} \\
(\mathbf{n}=\mathbf{3})\end{array}$ \\
\hline 0 & 0 \\
\hline 6 & $0.222 \pm 0.001$ \\
\hline 8 & $0.249 \pm 0.001$ \\
\hline 10 & $0.359 \pm 0.001$ \\
\hline 12 & $0.413 \pm 0.001$ \\
\hline 14 & $0.480 \pm 0.001$ \\
\hline 16 & $0.554 \pm 0.001$ \\
\hline 18 & $0.620 \pm 0.001$ \\
\hline 20 & $0.689 \pm 0.001$ \\
\hline
\end{tabular}

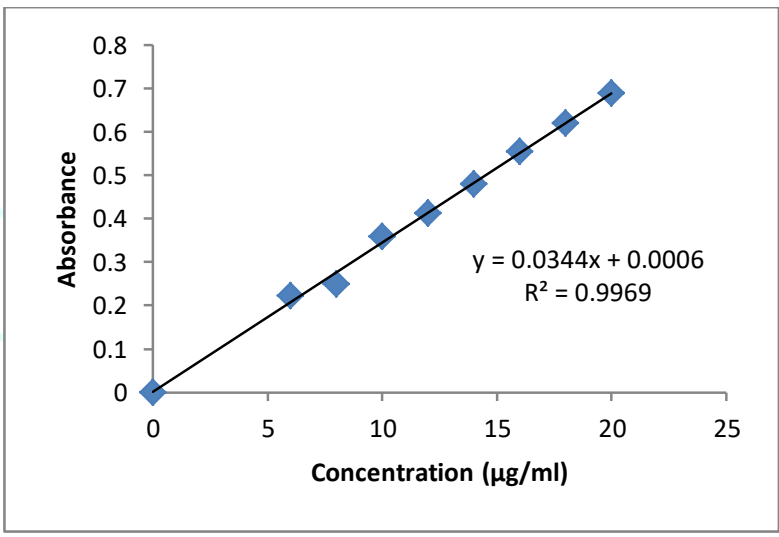

Figure 3: Calibration curve of Piroxicam in phosphate buffer pH 6.8

Table 4: Solubility studies of Piroxicam in different solvents

\begin{tabular}{|c|c|c|c|}
\hline Sr. NO. & Solvent used & Solubility $(\mathbf{m g} / \mathbf{m l})$ & Solubility profile \\
\hline 1 & Methanol & 7.26 & Soluble \\
\hline 2 & Water (pH 7.0) & 0.022 & Very slightly soluble \\
\hline 3 & Phosphate buffer pH 6.8 & 0.236 & Slightly soluble \\
\hline 4 & $\mathrm{pH} 4.0$ & 0.029 & Very slightly soluble \\
\hline 5 & $\mathrm{pH} \mathrm{7.0}$ & 0.556 & Slightly soluble \\
\hline 6 & $0.1 \mathrm{~N} \mathrm{HCl}$ & 0.417 & Slightly soluble \\
\hline
\end{tabular}




\section{Drug excipient compatibility study by FTIR}

The IR spectrum of physical mixture of pure drug and excipients were recorded by IR spectroscopy. The IR spectrum of drug and excipients did not show any significant change in the characteristic peaks of drug, which showed that superdisintegrants and drug were compatible with each other (Figure 4).

Table 5: Infrared spectral band of Piroxicam

\begin{tabular}{|c|c|c|c|}
\hline Sr.No. & Functional group & Observed peaks $\mathbf{( c m}^{-1} \mathbf{)}$ & $\begin{array}{c}\text { Reported peaks } \\
\text { (cm-1) }\end{array}$ \\
\hline 1 & Ortho-di substituted ring & 773.46 & 775 \\
\hline 2 & $\mathrm{SO}_{2}$-NH group & 1149.57 & 1149 \\
\hline 3 & Pyridine & 1300.02 & 1298 \\
\hline 4 & Methyl & 1435.04 & 1435 \\
\hline 5 & Tertiary amine group & 1525.69 & 1524 \\
\hline 6 & Amide carbonyl & 1629.85 & 1629.85 \\
\hline 7 & Cubic polymorphic form & 3338.78 & 3338.78 \\
\hline
\end{tabular}

Table 6: FTIR studies of Piroxicam with superdisintegrants

\begin{tabular}{|c|c|c|c|c|}
\hline \multirow{2}{*}{ IR spectra } & \multicolumn{4}{|c|}{ Peak of functional groups [Wave length $\left(\mathbf{c m}^{-1} \mathbf{)}\right]$} \\
\cline { 2 - 5 } & $\boldsymbol{N}$-H stretch & C-H stretch & C=C stretch & OH bend \\
\hline Standard spectra & 3339.028 & 2933.879 & 1529.315 & 939.582 \\
\hline Piroxicam & 3338.78 & 2931.88 & 1525.69 & 939.33 \\
\hline Piroxicam + CCS & 3337.96 & 2932.89 & 1529.62 & 938.41 \\
\hline Piroxicam + crospovidone & 3337.96 & 2933.85 & 1530.58 & 938.41 \\
\hline Piroxicam + SSG & 3337.96 & 2932.89 & 1531.55 & 938.41 \\
\hline
\end{tabular}

\section{Precompression parameters}

The values of precompression parameters evaluated were found to be within the prescribed limits and indicated good free flowing property. Data are tabulated in Table 7.

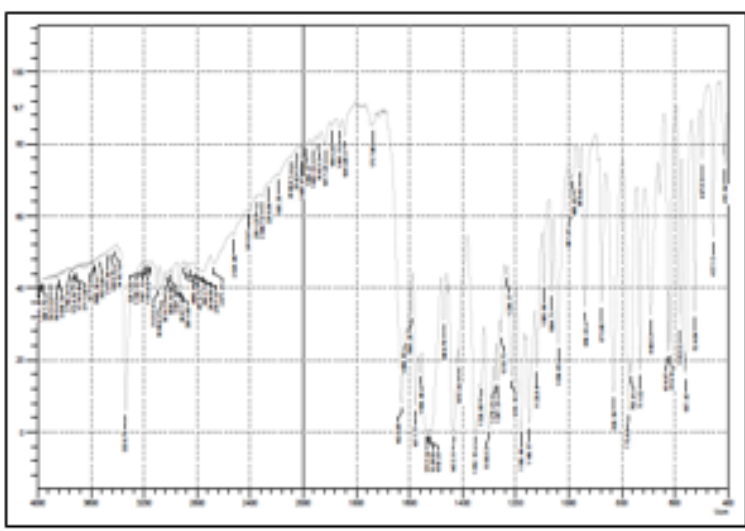

(a)

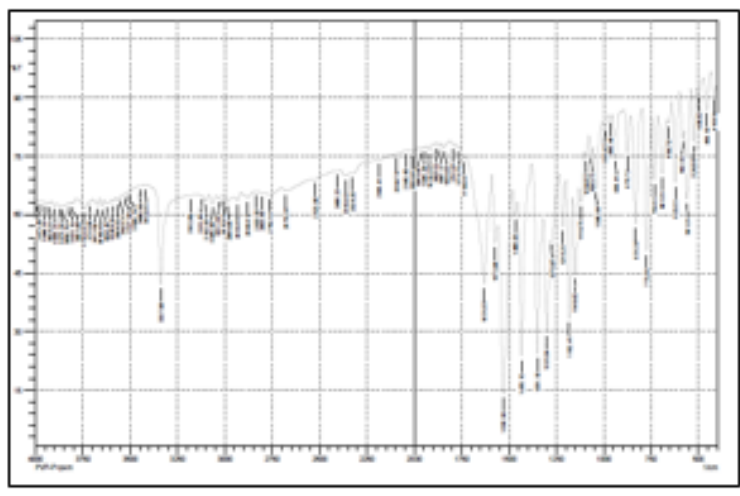

(c)

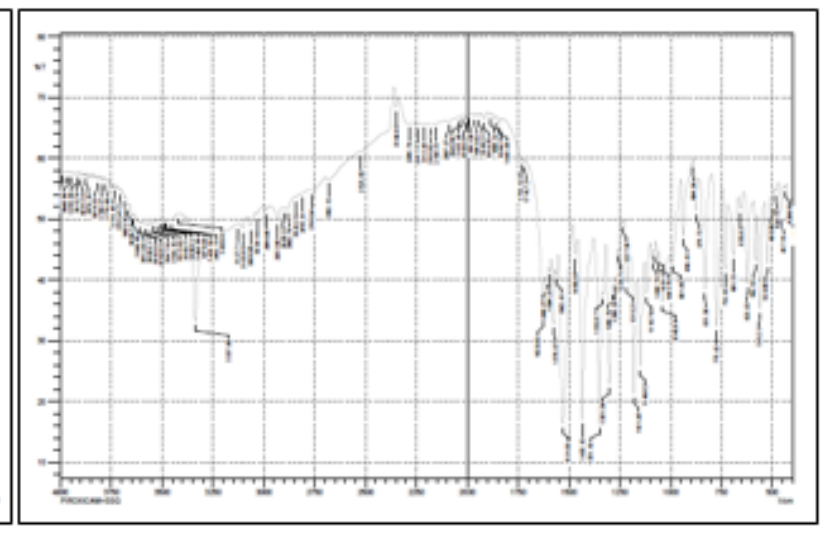

(b)

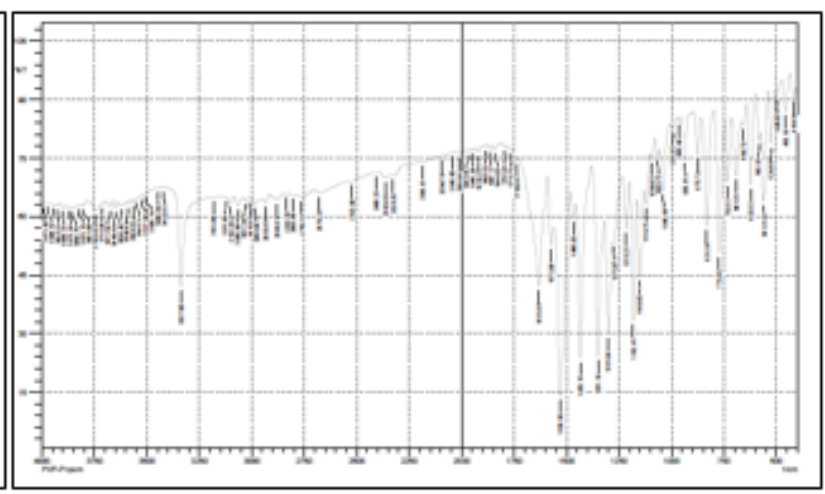

(d)

Figure 4: FTIR spectrum of (a) PXM, (b) SSG and PXM, (c) CP and PXM, (d) CCS and PXM 
Table 7: Precompression parameters of powder blend

\begin{tabular}{|c|c|c|c|c|c|}
\hline $\begin{array}{c}\text { Formulation } \\
\text { code }\end{array}$ & $\begin{array}{c}\text { Angle of repose } \\
(\theta)\end{array}$ & $\begin{array}{c}\text { Bulk density } \\
(\mathrm{g} / \mathrm{ml})\end{array}$ & $\begin{array}{c}\text { Tapped density } \\
(\mathrm{g} / \mathrm{ml})\end{array}$ & Hausner's ratio & Carr's index (\%) \\
\hline PXM1 & $31.63 \pm 0.563$ & $0.326 \pm 0.009$ & $0.376 \pm 0.011$ & $1.15 \pm 0.010$ & $13.37 \pm 0.495$ \\
\hline PXM2 & $30.55 \pm 0.527$ & $0.376 \pm 0.018$ & $0.437 \pm 0.017$ & $1.15 \pm 0.012$ & $13.89 \pm 0.870$ \\
\hline PXM3 & $28.58 \pm 0.450$ & $0.342 \pm 0.019$ & $0.423 \pm 0.021$ & $1.23 \pm 0.005$ & $19.143 \pm 0.491$ \\
\hline PXM4 & $28.15 \pm 0.30$ & $0.357 \pm 0.015$ & $0.411 \pm 0.018$ & $1.13 \pm 0.030$ & $13.13 \pm 0.253$ \\
\hline PXM5 & $27.88 \pm 0.627$ & $0.444 \pm 0.013$ & $0.526 \pm 0.015$ & $1.173 \pm 0.001$ & $14.75 \pm 0.108$ \\
\hline PXM6 & $25.41 \pm 0.685$ & $0.457 \pm 0.015$ & $0.553 \pm 0.018$ & $1.21 \pm 0.003$ & $17.367 \pm 0.220$ \\
\hline PXM7 & $30.240 \pm 0.617$ & $0.561 \pm 0.003$ & $0.646 \pm 0.006$ & $1.152 \pm 0.005$ & $13.197 \pm 0.336$ \\
\hline PXM8 & $28.990 \pm 0.298$ & $0.620 \pm 0.006$ & $0.705 \pm 0.004$ & $1.136 \pm 0.004$ & $12.007 \pm 0.332$ \\
\hline PXM9 & $33.170 \pm 0.706$ & $0.478 \pm 0.002$ & $0.558 \pm 0.003$ & $1.167 \pm 0.003$ & $14.383 \pm 0.224$ \\
\hline PXM10 & $26.880 \pm 0.355$ & $0.508 \pm 0.002$ & $0.624 \pm 0.018$ & $1.182 \pm 0.006$ & $15.427 \pm 0.42$ \\
\hline PXM11 & $27.967 \pm 0.182$ & $0.410 \pm 0.005$ & $0.493 \pm 0.009$ & $1.197 \pm 0.005$ & $16.497 \pm 0.341$ \\
\hline PXM12 & $27.697 \pm 0.405$ & $0.517 \pm 0.007$ & $0.590 \pm 0.007$ & $1.140 \pm 0.008$ & $12.263 \pm 0.617$ \\
\hline
\end{tabular}

Mean \pm SD $(n=3)$

\section{Post compression parameters}

Post-compression evaluations of all formulations were carried out successfully and data are tabulated Table 8 and Table 9 respectively.

Table 8: Post compression parameters of prepared fast dissolving tablets

\begin{tabular}{|c|c|c|c|c|c|}
\hline $\begin{array}{l}\text { Formulation } \\
\text { code }\end{array}$ & $\begin{array}{l}\text { Hardness } \\
\left(\mathrm{kg} / \mathrm{cm}^{3}\right)\end{array}$ & Friability (\% age) & Thickness (mm) & $\begin{array}{c}\text { Weight } \\
\text { variation }\end{array}$ & Drug content $(\%)$ \\
\hline PXM1 & $3.500 \pm 0.300$ & $0.534 \pm 0.093$ & $3.546 \pm 0.069$ & Pass & $98.730 \pm 0.611$ \\
\hline PXM2 & $3.067 \pm 0.208$ & $0.568 \pm 0.034$ & $3.569 \pm 0.068$ & Pass & $99.36 \pm 0.959$ \\
\hline PXM3 & $3.467 \pm 0.115$ & $0.480 \pm 0.076$ & $3.464 \pm 0.053$ & Pass & $100.24 \pm 0.641$ \\
\hline PXM4 & $3.500 \pm 0.173$ & $0.375 \pm 0.144$ & $3.552 \pm 0.045$ & Pass & $100.19 \pm 0.386$ \\
\hline PXM5 & $3.900 \pm 0.100$ & $0.659 \pm 0.191$ & $3.425 \pm 0.034$ & Pass & $99.850 \pm 0.200$ \\
\hline PXM6 & $3.800 \pm 0.300$ & $0.672 \pm 0.016$ & $3.457 \pm 0.038$ & Pass & $99.250 \pm 0.522$ \\
\hline PXM7 & $3.467 \pm 0.896$ & $0.593 \pm 0.042$ & $3.376 \pm 0.053$ & Pass & $97.033 \pm 0.533$ \\
\hline PXM8 & $3.500 \pm 0.781$ & $0.579 \pm 0.049$ & $3.390 \pm 0.047$ & Pass & $99.157 \pm 0.400$ \\
\hline PXM9 & $3.630 \pm 0.551$ & $0.775 \pm 0.056$ & $3.392 \pm 0.040$ & Pass & $99.037 \pm 0.352$ \\
\hline PXM10 & $4.430 \pm 0.777$ & $0.787 \pm 0.027$ & $3.367 \pm 0.026$ & Pass & $99.020 \pm 0.052$ \\
\hline PXM11 & $3.760 \pm 0.379$ & $0.643 \pm 0.049$ & $3.418 \pm 0.059$ & Pass & $98.773 \pm 0.336$ \\
\hline PXM12 & $3.860 \pm 0.306$ & $0.654 \pm 0.024$ & $3.369 \pm 0.040$ & Pass & $99.497 \pm 0.517$ \\
\hline
\end{tabular}

Mean \pm SD $(n=3)$,

Table 9: Post compression parameters of prepared fast dissolving tablets

\begin{tabular}{|c|c|c|c|}
\hline $\begin{array}{c}\text { Formulation } \\
\text { code }\end{array}$ & $\begin{array}{c}\text { Disintegration time } \\
\text { (sec) }\end{array}$ & Wetting time (sec) & $\begin{array}{c}\text { Water Absorption Ratio } \\
\text { (\%) }\end{array}$ \\
\hline PXM1 & $54.787 \pm 0.514$ & $23.987 \pm 0.991$ & $64.813 \pm 0.836$ \\
\hline PXM2 & $46.23 \pm 0.404$ & $19.840 \pm 0.643$ & $73.397 \pm 0.309$ \\
\hline PXM3 & $33.8 \pm 0.625$ & $26.050 \pm 0.821$ & $73.420 \pm 0.305$ \\
\hline PXM4 & $18.667 \pm 0.577$ & $10.410 \pm 0.637$ & $94.997 \pm 0.154$ \\
\hline PXM5 & $58.35 \pm 0.673$ & $57.66 \pm 0.577$ & $71.070 \pm 0.298$ \\
\hline PXM6 & $60.700 \pm 0.608$ & $42.673 \pm 0.769$ & $62.127 \pm 0.633$ \\
\hline PXM7 & $51.200 \pm 0.779$ & $56.267 \pm 0.681$ & $65.867 \pm 0.351$ \\
\hline PXM8 & $38.100 \pm 0.850$ & $43.467 \pm 0.961$ & $83.700 \pm 0.458$ \\
\hline PXM9 & $66.300 \pm 0.557$ & $68.600 \pm 0.794$ & $55.100 \pm 0.624$ \\
\hline PXM10 & $59.900 \pm 0.500$ & $62.067 \pm 0.513$ & $62.133 \pm 0.351$ \\
\hline PXM11 & $71.067 \pm 0.416$ & $72.700 \pm 0.458$ & $69.600 \pm 0.700$ \\
\hline PXM12 & $64.367 \pm 0.416$ & $66.400 \pm 0.300$ & $60.600 \pm 0.458$ \\
\hline
\end{tabular}


Dissolution studies were conducted for all the formulation via USP dissolution apparatus II paddle type, using phosphate buffer $\mathrm{pH} 6.8$ as dissolution medium. It had been observed from the drug release profile more than $90 \%$ drug was released within $20 \mathrm{~min}$. Tablets which were formulated by the direct compression method showed more than $75 \%$ of the drug release within 15 min. Formulation PXM4 containing $5 \%$ crospovidone showed $99.450 \pm 0.260 \%$ drug release within 15 min which was formulated by the direct compression method. Formulation PXM8 that was formulated by sublimation method containing $5 \%$ crospovidone and $3 \%$ camphor as sublimating agent showed $95.94 \pm 0.205 \%$ drug release within $15 \mathrm{~min}$ that was less as compared to the formulation PXM4. Cumulative percent drug release of all formulations is tabulated below in Table 10. Comparative drug release of the all the formulations were showed in the Figure 5.

Table 10: In-vitro dissolution profile data of formulations PXM1-PXM12

\begin{tabular}{|c|c|c|c|c|c|}
\hline \multirow{2}{*}{$\begin{array}{c}\text { Formulation } \\
\text { Code }\end{array}$} & $\mathbf{5}$ & $\mathbf{5}$ & \multicolumn{5}{|c|}{ Time (min) } \\
\cline { 2 - 6 } & $\mathbf{0}$ & $\mathbf{5}$ & $\mathbf{1 0}$ & $\mathbf{2 0}$ \\
\hline PXM1 & 0 & $60.280 \pm 0.567$ & $67.893 \pm 0.787$ & $79.260 \pm 0.910$ & $96.043 \pm 0.614$ \\
\hline PXM2 & 0 & $63.240 \pm 0.490$ & $71.107 \pm 0.510$ & $87.113 \pm 0.345$ & $99.040 \pm 0.445$ \\
\hline PXM3 & 0 & $63.050 \pm 0.790$ & $75.050 \pm 0.753$ & $83.193 \pm 0.710$ & $98.057 \pm 0.819$ \\
\hline PXM4 & 0 & $68.950 \pm 0.785$ & $85.163 \pm 0.550$ & $99.450 \pm 0.260$ & $99.480 \pm 0.291$ \\
\hline PXM5 & 0 & $60.980 \pm 0.516$ & $74.667 \pm 0.451$ & $81.370 \pm 0.488$ & $96.427 \pm 0.407$ \\
\hline PXM6 & 0 & $63.14 \pm 0.651$ & $76.687 \pm 0.539$ & $86.920 \pm 0.570$ & $99.087 \pm 0.619$ \\
\hline PXM7 & 0 & $54.22 \pm 0.477$ & $68.60 \pm 0.484$ & $85.24 \pm 0.514$ & $93.26 \pm 0.462$ \\
\hline PXM8 & 0 & $77.06 \pm 0.385$ & $88.04 \pm 0.118$ & $95.94 \pm 0.205$ & $99.09 \pm 0.140$ \\
\hline PXM9 & 0 & $51.00 \pm 0.811$ & $64.25 \pm 0.715$ & $73.66 \pm 0.728$ & $88.34 \pm 0.558$ \\
\hline PXM10 & 0 & $56.22 \pm 0.293$ & $71.80 \pm 0.210$ & $82.73 \pm 0.400$ & $94.83 \pm 0.401$ \\
\hline PXM11 & 0 & $51.10 \pm 0.394$ & $68.08 \pm 0.346$ & $84.07 \pm 0.681$ & $93.20 \pm 0.433$ \\
\hline PXM12 & 0 & $64.67 \pm 0.548$ & $78.55 \pm 0.513$ & $89.17 \pm 0.201$ & $96.64 \pm 0.557$ \\
\hline
\end{tabular}

Mean (\%CDR) \pm SD $(n=3)$,

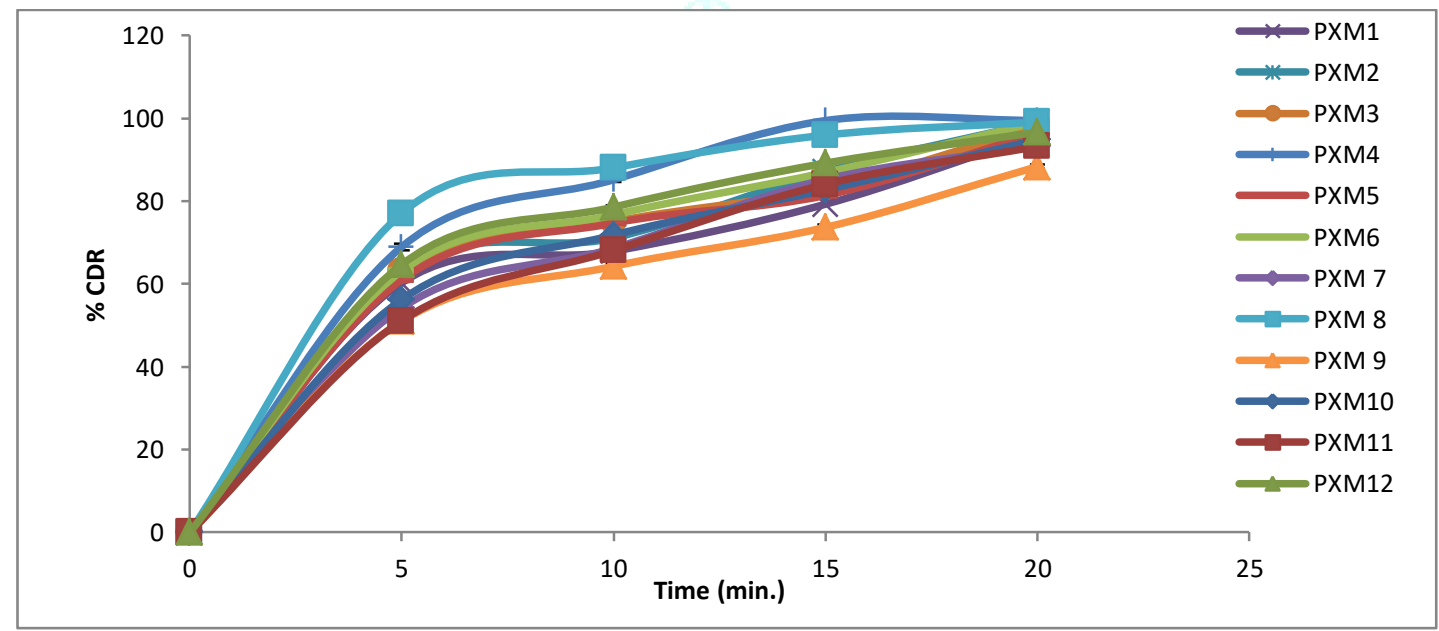

Figure 5: Comparison of percent cumulative drug release of all the formulations PXM1 to PXM12

From the above data, it was observed that formulation PXM 4 containing $5 \%$ crospovidone formulated by the direct compression method showed fastest drug release when compared with the all other formulations. The best-selected formulation PXM 4 was chosen for comparison with marketed formulations. Formulation PXM4 was compared with two different marketed formulations of different brands. Comparison indicated that the prepared formulation
PXM4 containing $5 \%$ crospovidone showed $99.667 \pm 0.244$ $\%$ drug release in 15 min whereas marketed formulation MKT1 and MKT2 showed 89.017 $0.091 \%$ and $85.013 \pm$ $0.119 \%$ drug release within 15 min that was less than formulation PXM4. The comparison of percent drug release of optimized formulation with marketed formulation is shown in the Table 11 and in Figure 6. 
Table 11: Comparison of the optimized formulation with the marketed formulations

\begin{tabular}{|c|c|c|c|}
\hline Time (min.) & PXM4 & MKT1 & MKT2 \\
\hline 0 & 0 & 0 & 0 \\
\hline 5 & $76.900 \pm 0.324$ & $72.993 \pm 0.206$ & $68.530 \pm 0.426$ \\
\hline 10 & $87.330 \pm 0.361$ & $81.737 \pm 0.555$ & $76.993 \pm 0.111$ \\
\hline 15 & $99.667 \pm 0.244$ & $89.017 \pm 0.091$ & $85.013 \pm 0.119$ \\
\hline 20 & $99.397 \pm 0.751$ & $90.950 \pm 0.060$ & $95.003 \pm 0.179$ \\
\hline
\end{tabular}

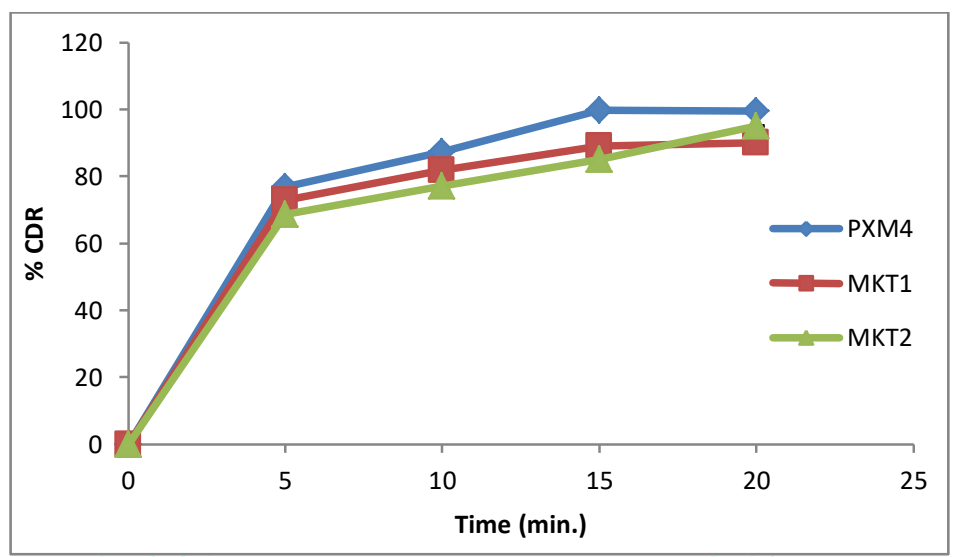

Figure 6: Comparison of the optimized formulation with the marketed formulations

\section{Statistical analysis}

It was found to be significant indicating there is no significant difference in the release profile of formulated FDTs and marketed formulations.

\section{Stability study of optimized formulation}

The optimized formulation PXM4 The fast dissolving tablets were packed in suitable packaging and stored at $40.0{ }^{\circ} \mathrm{C} \pm$ $2.0{ }^{\circ} \mathrm{C}$ and $\mathrm{RH} 75 \% \pm 5 \%$ for 90 days. After 90 days the tablets were evaluated for physical appearance, drug content, disintegration time, wetting time and in-vitro drug release studies. Stability data for the optimized formulation is shown in the Table 12 . No significant changes were seen in drug content, disintegration time, wetting time and in-vitro drug release. Stability study of optimized formulation PXM4 was found to be stable and compiles with Pharmacopeias standards.

Table 12: Drug release from the formulation PXM4 during stability studies

\begin{tabular}{|c|c|}
\hline \multicolumn{2}{|c|}{ Sampling time (90 days) } \\
\hline Time (min.) & \% CPR \pm SD (n=3) \\
\hline 0 & 0 \\
\hline 5 & $66.163 \pm 0.280$ \\
\hline 10 & $82.257 \pm 0.435$ \\
\hline 15 & $94.320 \pm 0.802$ \\
\hline 20 & $97.120 \pm 0.147$ \\
\hline
\end{tabular}

\section{CONCLUSION}

Fast dissolving tablets were prepared in two different methods viz. direct compression and sublimation. Preformulations parameters like the physical characterization of the drug were evaluated. All the Piroxicam fast dissolving tablets were showed more than $80 \%$ drug release within the 15 min. Formulation PXM4 containing $5 \%$ crospovidone prepared by direct compression was found to be better in terms of rapid disintegration and maximum percentage drug release when compared with all other formulations and marketed formulation. It shows disintegration time of $18.667 \pm 0.577 \mathrm{sec}$ and $99.450 \pm 0.260 \%$ drug release in 15 min. Stability studies revealed that there were no significant changes seen in physical appearance, drug content, disintegration time and in-vitro drug release during the storage of optimized formulation PXM4 for 90 days. Thus, Piroxicam can be successfully prepared using direct compression technique and it will enhance the drug dissolution, which will further increase absorption and bioavailability of the drug.

\section{CONFLICT OF INTEREST: None declared}

\section{REFERENCES}

1. Momin MM, Dev A. Fast dissolving tablets: a novel approach. Indian J. Pharm. Biol. Res. 2015; 3(1):18-23.

2. Heer D, Aggarwal G, Kumar SLH. Recent trends of fast dissolving drug delivery system - an overview of formulation technology. Pharmacophore: An International Research Journal. 2013; 4(1):1-9.

3. Desale KY, Bankar VH, Gaikwad PD, Pawar SP. Review on fast dissolving/disintegrating tablets. Int. J. Pharm. Sci. Review \& Res. 2011; 11(1):152-158.

4. Shukla D, Chakraborty S, Singh S, Mishra B. Mouth dissolving tablets: an overview of formulation technology. Sci Pharm. 2009; 76:309-326.

5. Srivastava S, Bala R, Joshi B, Rana AC, Singh V. Mouth dissolving tablets: a future compaction. Int. Res. J. Pharmacy. 2012; 3(8):98-109.

6. Hannan PA, Khan JA, Safiullah S. Oral dispersible system: a new approach in drug delivery system. Indian J. Pharm. Sci. 2016; 78(1):2-7.

7. Lindgren S, Janzon L. Dysphagia: prevalence of swallowing complaints and clinical finding. Med. Clin. North Am. 1993; 77:3-5.

8. Parashar B, Yadav V, Maurya B, Sharma L. Fast dissolving tablet. Int. J. App. Pharm. 2012; 4(2):17-22. 
9. Pandey P, Dahiya M. Oral disintegrating tables: a review. Int. J. Pharma Res. \& Review. 2016; 5(1):50-62.

10. Mettu SR, Veerareddy PR. Formulation evaluation and pharmacokinetics of flurbiprofen fast dissolving tablet. British. J. Pharm. Res. 2013; 3(4):617-631.

11. Katzung BG. Basic and clinical pharmacology. $10^{\text {th }}$ ed. McGraw companies. U.S.A. 2007, pp. 816.

12. Adeyeye MC, Brittain HG. Preformulation in solid dosage form development. Informa health care. USA. 2008; 178, pp. 1-2.

13. Singh NS, Patil UK. Solubility and preformulation study of non micronized piroxicam SEDSS. Journal of Pharmaceutical Research \& clinical Practice. 2014; 4(1):42-52.

14. Ashform M. Assessment of biopharmaceutical properties. In: Aulton ME. Aulton's pharmaceutics the design and manufacturing of medicines. $3^{\text {rd }}$ ed. Churchill Livingstone, $p$. 304-322.

15. Jabbbar ASA, Hussein AA. Formulation of piroxicam liquisolid compacts. Int. J. Pharm. Sci. 2012; 5(1):132-141.

16. Singh S, Shyale SS, Bhosale G. Formulation and evaluation of mouth dissolving tablets of piroxicam. Int. J. Pharm. Sci. Nanotech. 2015; 8(3):2941-2946.

17. Ravi KN, Palanichamy S, M Rajesh T, Godwin Rajadhas, V Anusha, N Parasakthi, Thirupathi AT. Formulation and evaluation of orodispersible piroxicam tablets. J. Pharm. Sci. \& Res. 2010; 2(10):615-621.

18. Patil BS, Rao DK, Kulkarni U, RC Hariprasanna, Gada M.M. Formulation and evaluation of fast dissolving tablets of granisetron hydrochloride by direct compression technique. Int. Curr. Pharm. Res. 2011; 3(2):124-128.

19. Modasiya MK, Lala II, Prajapati BG, Patel VM, Shah DA. Design and characterization of fast dissolving tablets of piroxicam. Int. J. PharmTech. Res. 2009; 1(2):353-357.

20. Chaudhari KP, Jadhao UT, Chaudhari CD, Thakare VM, Tekade BW, Chaudhari CS. Formulation and evaluation of fast dissolving sublingual tablets of amlodipine besylate. Der Pharmacia Sinica. 2014; 5(4):1-9.

21. Jalwal MP, Nirja R. Formulation and evaluation of fast dissolving tablet of Domperidone. Int. J. Pharma Professional Res. 2014; 5(3):1067-1074

22. Kurra N, Baru CR, Vidyadhara KP, Vanitha. Formulation and evaluation of fast dissolving sublingual lisinopril tablets. Indo
American Journal of Pharmaceutical Sciences. 2014; 1(6):378391.

23. Khokhar P, Shukla V. Formulation and evaluation of fast dissolving tablets of diclofenac sodium using PVP. Int. J. Pharma. Res. \& Review. 2014; 3(7):12-19.

24. Rajput N, Thakare VM, Tekade BW, Chaudhari KP, Jadhao UT. Formulation and evaluation of fast dissolving tablet by inclusion complexation. Asian Journal of Pharmaceutical Science \& Technology. 2014; 4(1):15-20.

25. Padmaja B, Ramakrishna R, Goud G. Formulation and evaluation of fast dissolving tablets of ranitidine hydrochloride. Journal of Pharmacy Research. 2015; 9(2):165-169.

26. Nagar PK, Nayyar P, Sharma PK. Formulation and evaluation of piroxicam fast dissolving tablets using different natural superdisintegrants. Journal of Drug Delivery \& Therapeutics. 2014; 4(4):55-59.

27. Iyer S, Sivakumar R, Siva P, Sajeeth CI. Formulation and evaluation of fast dissolving tablets of risperidone solid dispersion. Int. J. Pharmaceutical, Chemical and biological Sciences. 2013; 3(2):388-397.

28. Palanichamy S, Kiran NR, M Rajesh, Jeganath S, Thangathirupathi A. Formulation development and evaluation of piroxicam orodispersible tablets using different superdisintegrant. Des. Pharmacia Lettre. 2011; 3(4):155162 .

29. Nagendra DK, Keshavshetti GG, Pratibha. Design and evaluation of fast dissolving tablets of metoclopramide hydrochloride using synthetic and natural superdisintegrants. Unique Journal of Pharmaceutical and Biological Sciences. 2014; 2(1):16-24.

30. Sudarsanam P, Balakrishanan M, Sireesha VR, Prasad PV. Saitha Kommi. Formulation and evaluation of piroxicam delayed release tablets. Int. J. Pharm.Drug. Anal. 2016; 4(6):318-328.

31. Bhargav E, Reddy CSP, Sowmya C, Haranath C, Khan KAA, K Rajesh et al., Formulation and optimization of piroxicam orodispersible tablets by central composite design. J. Young Pharm. 2017; 9(2):187-191. 